\title{
Environmental lead and its paediatric significance
}

\author{
DONALD BARLTROP \\ B.Sc., M.D.(Lond.), M.R.C.P., D.C.H. \\ Wellcome Senior Research Fellow in Clinical Science, Paediatric Unit, St Mary's Hospital Medical School, \\ London, $W .2$
}

\section{Introduction}

Although paediatricians are familiar with the problem of childhood lead poisoning in association with the ingestion of lead paint, little attention has been given to the problem of other environmental sources of lead. Since both nature and industry continuously transfer lead from the lithosphere to the biosphere, it is appropriate to consider the magnitude of these contributions and their significance for the human foetus and child.

The total body burden for lead of man in his natural state is calculable, and would be about 2 $\mathrm{mg}$ compared with $200 \mathrm{mg}$ in many civilized communities. The magnitude of present day environmental lead contamination is emphasized by the recent calculation that 20 tons of lead are consumed annually by the population of the United States (Patterson, 1965). Comparison of the daily ingested and inhaled burdens of lead with the total daily intake which will precipitate poisoning, provides some measure of the importance of environmental lead for children.

Until recently few estimates of this were available; however, on the basis of faecal lead determinations it can be shown that the ingestion of as little as $1 \mathrm{mg} /$ day by a 2-year-old child during a 6-month period might cause lead poisoning (Barltrop \& Killala, 1967). Since 200-300 $\mu \mathrm{g}$ of lead might be ingested from 'normal' sources it will be apparent that this may form a substantial proportion of the lead burden responsible for poisoning. Restriction of the environmental lead burden might at least postpone the onset of poisoning in a child with pica for leadcontaining materials and perhaps diminish the severity of a poisoning episode.

Whether the continued exposure of sections of the population to increased environmental lead levels has any other significance, apart from increasing the likelihood of childhood lead poisoning, has yet to be determined. The lead industry tends to minimize the attendant dangers and points to the relatively high levels of exposure that are apparently safely tolerated by lead workers. The appropriate health standards that have been devised for industry are based on the requirements of healthy adult males exposed to lead during a 40-hr working week. It has been cogently argued that the standards for lead workers might not be applicable to other population groups which are continuously exposed to lower levels; the foetus and the child would seem to deserve particular attention with regard to this environmental problem (Hardy, 1966). Some natural environmental lead is radioactive ${ }^{210} \mathrm{~Pb}$ and this provides an additional reason for minimizing the total body lead burden.

The study of the origins and distribution of stable and radioactive lead has been pursued in a variety of disciplines with which the paediatrician has little contact. It is hoped that this review of some aspects of the problem might stimulate a reconsideration of the relevance of this element for human growth and development.

\section{Production and utilization}

Lead is produced by smelting the ore galena (lead sulphide). This substance is widely distributed and occurs in both surface and underground deposits. Many countries have lead mining interests and Australia is now the world's largest lead producer. Production figures are not the best guide to utilization since there is considerable recycling of this valuable metal as scrap through secondary smelters. The production and consumption figures for the United States have recently been reported in detail and in summary concern some $1,100,000$ short tons/ annum, of which about $60 \%$ is metallic lead and the remainder is in a wide variety of lead compounds (Ziegfeld, 1964). The major industries utilizing lead are listed in Table 1 together with their percentage share of the total annual consumption.

Two items in the United States figures deserve particular note although they will be referred to again in more detail, firstly 175,000 tons utilized in the production of petrol, since much of this will eventually be distributed into the atmosphere as automobile exhaust, secondly 2500 tons of lead arsenate intended for application to food-crops as a pesticide. 
TABLE 1. Lead consumption by industry in the United States (after Ziegfeld, 1964)

\begin{tabular}{ll}
\hline Industry & $\%$ \\
\hline Storage batteries & 35 \\
Petrol & 16 \\
Building & 11 \\
Brass, ceramics, type, paint & 15 \\
Other & 23 \\
\hline
\end{tabular}

Among the many uses for lead are some which may not be easily recognized, e.g. lead compounds as stabilizers in certain plastics. New uses are continually sought and the application of organo-leads as biocides in wood and fabric preservation and even bilharzial control are being studied (Van der Kerk, 1966). Although organic compounds of lead have their own toxicity characteristics, ultimately they are all likely to be degraded and to release lead in the inorganic form.

The industrial contribution to environmental lead may result from the emission of lead particles into the atmosphere and by pollution of natural waters with lead-containing industrial effluents. Polluted atmosphere and water both serve to contaminate soil, plants and foodstuffs, thus both atmosphere and diet contribute to the daily lead intake.

\section{Atmospheric lead}

Since their introduction into petrol in 1923 nearly 3 million tons of lead alkyls have been marketed (Chow \& Johnstone, 1965). After combustion, the anti-knock derivatives in petrol are released in inorganic form as a mixture of halides and oxides. Atmospheric pollution has occurred on a world scale and affected even remote regions; thus serial samples of Greenland snow since 1900 have shown a sharp increase in lead content during recent decades (Murozumi, Chow \& Patterson, 1964).

The blood lead of persons living close to regions of high traffic density such as motorways has been shown to be significantly higher $(22.7 \mu \mathrm{g} / 100 \mathrm{~g})$ than that of comparable individuals in an area remote from heavy traffic $(16.0 \mu \mathrm{g} / 100 \mathrm{~g})$. Residence 150 $\mathrm{ft}$ from a motorway was also associated with a significant reduction in blood lead concentration (Thomas et al., 1967). A similar decrease is observed in the occupants of high level apartments since the atmospheric lead content decreases sharply with increasing height above the source.

Few studies concerning children have been made. In Sofia, Petrova, Dalakmanski \& Bakalov (1966) studied a group of forty-eight children aged 5-7 years and found that they excreted significantly more coproporphyrin $(40.3 \mu \mathrm{g} / 24 \mathrm{hr})$ than a control group in the suburbs $(32.6 \mu \mathrm{g} / 24 \mathrm{hr})$. The maximum lead concentration in ambient air in Sofia was only
$6.3 \mu \mathrm{g} / \mathrm{m}^{3}$ as compared with $6 \mu \mathrm{g} / \mathrm{m}^{3}$ recorded 300 $\mathrm{ft}$ from a freeway at the fourth storey of a building in Los Angeles (Thomas et al., 1967), $9.8 \mu \mathrm{g} / \mathrm{m}^{3}$ in Paris (Truffert, Lebbe \& Chovin, 1966), and 11 $\mu \mathrm{g} / \mathrm{m}^{3}$ in Seoul (Kwon \& Kim, 1966).

Although automobile exhaust fumes are a major problem in the Northern Hemisphere, industrial undertakings also make a significant, if local, contribution. In areas close to lead smelters or installations for the burning and distillation of coal, significant atmospheric pollution with lead may occur and should be considered with regard to the local population. It is seldom realized that the atmospheric emissions from smelters may be very large; Chakraborty et al. (1964) reported one in India that discharged $2000 \mathrm{lb}(907 \mathrm{~kg})$ of lead into the atmosphere daily. A similar example in Rumania deposited sufficient lead on local foliage to precipitate acute lead poisoning in the local cattle that consumed it (Iosif, 1966).

Much industrial air pollution is of relatively large particle size so that a considerable fallout occurs near the source. Figures published for an Italian plant showed maximum concentrations of 490 $\mu \mathrm{g} / \mathrm{m}^{3}$ at $80 \mathrm{~m}$ from the plant, falling to $37 \mu \mathrm{g} / \mathrm{m}^{3}$ at $320 \mathrm{~m}$ (Coghi \& Bellelli, 1965).

It is often incorrectly assumed that children will not be exposed in an occupational sense to industrial or quasi-industrial lead fumes. Poisoning of adolescent children undergoing vocational training in school radio-assembly workshops in Russia, due to the use of solder containing $40 \%$ lead, has been reported (Lyubchenko, 1966). Similarly, the use of a lead frit in jewellery enamelling has been associated with abnormal absorption of lead and poisoning in the girls employed in this trade in Britain (Fothergill, Kipling \& Weber, 1967).

Acceptable limits for the lead content of ambient air have yet to be agreed. In most industrial settings a level of $200 \mu \mathrm{g} / \mathrm{m}^{3}$ is regarded as satisfactory for the limited exposure of adult males during the working week.

Kehoe has contributed much to the understanding of the inhalation of lead particles by studies on adult human volunteers with lead sesquioxide particles of $0.05 \mu$ mean diameter, and has suggested that a suitable limit might be $10 \mu \mathrm{g} / \mathrm{m}^{3}$ (Kehoe, 1966). His conclusions may not be applicable to children and pregnant women.

The state of Pennsylvania has recently adopted a tentative upper limit for atmospheric lead of $5 \mu \mathrm{g} / \mathrm{m}^{3}$ (Lead Industries Association, 1968) although road traffic exhaust fumes can cause this value to be exceeded in cities and near motorways (see above).

The biological significance of exposure to low atmospheric levels is difficult to determine since, although relatively small amounts are retained in the 
lung, absorption at that site is high and of the order of $30-50 \%$ of the inhaled lead. This contrasts with the gut, to which some of the lung lead is transferred by ciliary action, where only $10 \%$ of ingested lead is absorbed.

Using the International Commission for Radiation Protection (I.C.R.P.) 'Lung Dynamics Model', Kehoe (1967) has derived data that accord with his experimental studies and suggests that an acceptable lower limit for atmospheric lead would be $18 \mu \mathrm{g} / \mathrm{m}^{3}$ providing that it contained particles of $0.05 \mu$ diameter. Few data are available for children, but exposure of 11-year-old children to atmospheres with a mean lead content of $31 \mu \mathrm{g} / \mathrm{m}^{3}$ has been shown to result in increased 5-hydroxyindoleacetic acid excretion (Ghelberg, Goran \& Cheziv, 1966) and exposure to only $6 \mu \mathrm{g} / \mathrm{m}^{3}$ has resulted in increased coproporphyrin excretion (Petrova et al., 1966). Significantly raised bone lead contents have been observed in mice exposed to atmospheres containing only $2.6 \mu \mathrm{g} / \mathrm{m}^{3}$ for 15 -month periods (Cutmer, Busch \& Miller, 1967). Clearly the situation concerning children needs to be re-examined; future standards will need to define not only the total lead content per cu. $\mathrm{m}$ but also the population group to which the standard is intended to apply and to specify limits for factors such as particle size that are not at present considered.

\section{Water}

Natural waters contain lead derived from a number of sources including rocks and soil, particulate matter derived from atmospheric fallout and, in some instances, a contribution from sewage. Variations in the lead content of waters occur between different geographic regions and surface water has been found to contain 4-20 $\mu \mathrm{g} / 1$ compared with sea water which contained 3-5 $\mu \mathrm{g} / \mathrm{l}$. These figures contrast with those of well water consumed by a child with 'epilepsy' which had a lead content of $408 \mu \mathrm{g} / 1$ (Oyanguren \& Perez, 1966).

Contamination of reservoirs by air pollution is probably not yet a major problem, however in the Seattle region about $70 \mathrm{mg}$ of soluble lead settles on each square metre of surface per month derived largely from road traffic exhaust rather than industrial sources. The large volume of the reservoirs minimizes the effect of this fallout. In the winter, however, decreased utilization of water may result in a doubling of the lead content to $6 \mu \mathrm{g} / 1$ (Johnson, Rossano \& Sylvester, 1966). Recreational motor boats disperse $4 \times 10^{8} \mathrm{~g}$ of lead into natural waters in the United States each year from combustion of fuel containing lead alkyls (English, cit. Ettinger, 1967), but this is a small contribution compared with sewage which contributes a further $8 \times 10^{9}$ g/annum. Further contributions from industrial effluents occur in some watercourses and the remarkable figure of $800 \mu \mathrm{g} / \mathrm{l}$ has been recorded in the Ecourse river at Detroit. Providing that there is a high content of organic particulate matter, some degree of 'self-purification' takes place, presumably due to the combination of lead with the organic material (Solomin, Goncharova \& Fesenko, 1965).

The use of lead pipe, lead solder on copper pipe and occasionally even lead paint on water storage tanks, gives rise in many countries to a situation in which the lead content of the water supplied may differ greatly from the water actually consumed. Factors which influence the 'plumbosolvency' of a given water include the $\mathrm{pH}$ and the calcium content. Soft acid waters are especially liable to dissolve lead with which they come into contact. Thus prolonged standing in a pipe may result in some lead being dissolved and water in the terminal lead pipes of a dwelling will thus have an appreciably higher lead content after standing overnight. The WHO revised 1963 standard for drinking water set an upper limit of $50 \mu \mathrm{g} / 1$ for lead, but the WHO 'European' standard allows drinking water to contain up to $300 \mu \mathrm{g} / \mathrm{l}$ after standing in the pipe for $16 \mathrm{hr}$ (Annotation, 1967).

In Great Britain there are no legal standards for the lead content of water, although paradoxically there are limits for foodstuffs. Statutory bodies that supply water for domestic use are enjoined only to supply water that is 'wholesome'. A recent survey of eighteen towns in Great Britain showed that in four of them the lead content of domestic water, after standing overnight, exceeded $300 \mu \mathrm{g} / 1$ and in one case a value of $1200 \mu \mathrm{g} / 1$ was recorded (Crawford \& Morris, 1967). Even this figure has been exceeded and $25,000 \mu \mathrm{g} / \mathrm{l}$ was recently discovered in association with an overt case of lead poisoning (Bacon et al., 1967). It must be conceded that water normally contributes only a small proportion of the total intake of lead. In many regions only $2-3 \%$ of the total intake from all sources is contained in the water supply (Hadjimarkos, 1966). However, this proportion can easily be exceeded.

\section{Radioactive lead}

Radioactive lead is continuously deposited on the earth's surface as part of the 'natural' fallout, although it is increased after atmospheric nuclear detonations (Pierson, Cambray \& Spicer, 1966). Rocks containing radium continually liberate radon into the atmosphere, this in turn decays through a series of short lived isotopes to ${ }^{210} \mathrm{~Pb}$. This has a half-life of 22 years and ultimately decays through a further series of isotopes to stable lead. It has been calculated that $22 \times 10^{24}$ atoms of ${ }^{210} \mathrm{~Pb}$ are distributed over the earth's surface in this way each year (Lambert \& Nezami, 1961). 
The significance of this apparently trivial deposition is that the body cannot distinguish radioactive from stable lead and since this is a bone-seeking element the situation is analogous to that of the more familiar ${ }^{90} \mathrm{Sr}$. Indeed, it has been shown that there is a close correlation between the ${ }^{90} \mathrm{Sr}$ and the $210 \mathrm{~Pb}$ content of human bones. The vertebrae of children aged 3-12 months have been shown to contain 0.13 pCi/g Ca (Blanchard, 1966a) and it has been calculated that the radiation dose for the infant bones studied would have been 3.4 times greater than that due to ${ }^{90} \mathrm{Sr}$. In soft tissues human kidney and liver have been reported to contain 10.4 and $14.3 \mathrm{pCi} / \mathrm{kg}$, respectively (Blanchard, $1966 \mathrm{~b}$ ).

The cow, as might be expected, has a higher skeletal ${ }^{210} \mathrm{~Pb}$ content than man and analyses of mandibles have shown a mean ${ }^{210} \mathrm{~Pb}$ content of $0.74 \mathrm{pCi} / \mathrm{g}$ ash compared with an equivalent figure for man of $0.15 \mathrm{pCi} / \mathrm{g}$ ash (Lucas \& Di Ferrante, 1966).

The slow rate of growth and high capacity for the retention of trace elements of Arctic lichens is such that ${ }^{210} \mathrm{~Pb}$ contents five to ten times greater than those of annual plants in the same region occur. For this reason the Arctic food chain lichen-reindeer-man has aroused great interest. The intermediary of the reindeer has been shown to function as a 'biological filter' for man since much of the ${ }^{210} \mathrm{~Pb}$ absorbed is deposited in the reindeer skeleton and is thus excluded from the human diet (Kauranen \& Miettinen, 1966). The cow's skeleton in normal circumstances may have a similar action.

\section{Foodstuffs}

The contribution of foodstuffs to the daily lead burden of the adult is of the order of $300 \mu \mathrm{g} / \mathrm{day}$, but this is prone to local and geographical variation due to differences in preparation and distribution (Kehoe, Thamann \& Cholak, 1933). Variations in dietary patterns are also liable to modify the figure, and the high milk intake of young children and the high calorie requirements of the adolescent are good examples. Some animal tissues, such as liver and kidney, have a special affinity for lead so that the intake of lead from a diet rich in these might be higher than an equivalent diet based upon other tissues derived from the same animal. Typical figures for foodstuffs have been presented in Table 2, although it is stressed that these may be subject to wide local variations.

Plants and vegetables that are grown near to dense traffic routes are liable to contamination. Analyses of leaves taken from sites near highways in Great Britain have revealed mean lead contents of $87 \mathrm{mg} / \mathrm{kg}$ which is almost double the mean lead content of foliage from sites remote from traffic $(45 \mathrm{mg} / \mathrm{kg})$. The results were unrelated to the soil lead contents in which the plants grew (Everett, Day \& Reynolds, 1967). A seasonal variation in the lead content of pasture herbage has recently been

TABLE 2. Local content of foodstuffs (after Warren \& Delavault, 1962; Kehoe, Cholak \& Storey, 1940)

\begin{tabular}{lc}
\hline \multicolumn{1}{c}{ Food } & Lead $(\mu \mathrm{g} / \mathrm{kg})$ \\
\hline Cereals & $300-2000$ \\
Vegetables (root and leaf) & $30-600$ \\
Fruits & $3-120$ \\
Meats (beef) & $3-630$ \\
Eggs & $3-120$ \\
Milk (cow) & $20-40$ \\
Milk (human) & $0-100$ \\
\hline
\end{tabular}

described. During senescence a redistribution of lead ions occurs within the plant so that the above-ground portion may reach concentrations of $30-40 \mathrm{mg} / \mathrm{kg}$ during the winter compared with $0.3-1.5 \mathrm{mg} / \mathrm{kg}$ in the spring (Mitchell \& Reith, 1966). Levels of 40 $\mathrm{mg} / \mathrm{kg}$ are of importance to animals feeding on this material. The secondary problem of children consuming animal products derived from them has not yet been investigated. It is unlikely that a direct human parallel to this situation exists, but there is clearly a need to investigate the seasonal variation in the lead content of dietary constituents appropriate to different age-groups.

Lead poisoning in domestic animals, especially the calf, is common and several hundred deaths are reported each year (Ministry of Agriculture, Fisheries and Food, 1959). This is attributed to the tendency of bovines to suck, lick and chew painted surfaces. Analyses of milk in the United States have given a mean lead content of $49(23-79) \mu \mathrm{g} / \mathrm{kg}$. In the Cincinatti region, however, sporadic figures as high as $212 \mu \mathrm{g} / \mathrm{kg}$ have been observed and have been attributed to the ingestion of lead paint by cows. Milk containing lead in excess of $200 \mu \mathrm{g} / \mathrm{kg}$ represents an appreciable burden to those population groups which consume large quantities of cow milk, especially young children (Murchy, Rhea \& Peeger, 1967).

The use of lead-containing pesticides has already been cited, especially the use of lead arsenate sprays. Associated with the use of lead arsenate sprays raised lead concentrations have been found in fruit, tomatoes (Hamence, 1966), coffee beans (Pereira \& Echandi, 1964) and apples (Pocklington \& Tatton, 1966). Studies on imported apples by the latter authors have indicated that increased lead residues are obtained from apples from countries that allow the use of lead arsenate sprays compared with countries that do not. Thus apples imported from Canada where lead arsenate sprays are used may contain as much as $1750 \mu \mathrm{g} / \mathrm{kg}$, whereas South African apples contain only $100-300 \mu \mathrm{g} / \mathrm{kg}$. 


\section{Maturity and lead metabolism}

The manifestations of lead poisoning in children differ from those of adults in several respects (Barltrop, 1968a). Peripheral neuropathy is very rare and encephalopathy may supervene without a prolonged preceding symptomatic period. These differences may be due to different durations of exposure although recent data suggest that even childhood poisoning may occur only after several months' exposure (Barltrop \& Killala, 1967) and so not differ materally from many adult situations. Support for this may be derived from the numerous reports in the literature of lead poisoning in young and immature domestic animals often in circumstances in which adults of the same species were not affected. The prevalence of lead poisoning in calves has already been mentioned and similar reports concerning puppies (Berry, 1966), chicks (Cleef \& van Lensing, 1966) and lambs (Stewart \& Allcroft, 1956; Clegg \& Rylands, 1966) have appeared.

The tendency of the young of a given species to be more prone to lead poisoning than the corresponding adults might reflect the tendency of the immature to indulge in oral exploration of their environment, a tendency not unknown in children (Barltrop, 1966). Alternatively, the metabolic apparatus of the immature may be more liable to derangement by the presence of inorganic lead. If the latter were in fact the case, then clearly the whole question of environmental lead standards capable of general application will need to be reviewed. Experimental studies with guinea-pigs have shown that the young are relatively resistant to the effects of lead (Fullerton, 1966); however, further work with other animal species will be needed before this question can be clarified. Although the exposure of whole families to lead fumes from burning battery cases provides a situation in which children and adults have been equally exposed, this is difficult to prove in practice and almost impossible to assess retrospectively. Some reports have indicated that fatalities are confined to young children (Turner, Bamford \& Dodge, 1967).

Should the toxicity of lead be inversely proportional to the degree of maturation, the most severe effects might be expected in the foetus. Although placental transfer of lead normally occurs during human pregnancy (Horiuchi, Horiguchi \& Suekane, 1959; Barltrop, 1968b) the significance of this has not yet been evaluated. It is known that relatively severe exposure of pregnant women in industry may be followed by abortion (Legge \& Goadby, 1912; Taussig, 1936) and a recent example was with leadcontaining drinking water (Wilson, 1966). The detailed mechanism by which abortion is induced is not known but may represent a direct effect of lead on the chorio-epithelial cells rather than the foetus.
There is some evidence that lead may act as a teratogen, and developmental abnormalities of the tail and sacrum have been produced in foetal rats by the administration of lead compounds during pregnancy (Ferm \& Carpenter, 1967). Species differences might be expected and no teratogenic activity of lead could be discovered in the cow (Shupe et al., 1967) or sheep (James, Lazar \& Binns, 1966). The situation concerning the relationship of environmental lead to the induction of foetal abnormalities in the human is, as yet, unknown although obviously an abortifacient might well be capable of interfering with foetal nutrition at critical stages of development. Until further information becomes available it would seem reasonable to limit the exposure of the pregnant woman, and hence the foetus, to lead.

\section{Conclusions}

There is evidence that appreciable body burdens of stable and radioactive lead may be acquired by children and also that part of the maternal intake of lead may influence the foetus. The rapid growth rate, immature metabolic apparatus and varying dietary patterns which characterize the paediatric age-groups suggest that standards for adult males might not be applicable. Numerous environmental sources may contribute to the lead intake of children but the metabolism of lead in this group is not well understood and deserves further study.

\section{References}

AnNotation (1967) Lead in drinking water. Lancet, ii, 1076. Bacon, A.P.C., Froome, K., Gent, A.E., Cooke, T.K. \& Sowerby, P. (1967) Lead poisoning from drinking soft water. Lancet, i, 264.

BARLTROP, D. (1966) The prevalence of pica. Amer. J. dis. Child. 112, 116.

Barltrop, D. (1968a) Lead poisoning in childhood. Postgrad. med. J. 44, 537.

Barltrop, D. (1968b) The transfer of lead to the human foetus. Mineral Metabolism in Paediatrics. Blackwell Scientific Publications, Oxford (In press.)

Barltrop, D. \& Killala, N.J.P. (1967) Faecal excretion of lead by children. Lancet, ii, 1017.

BERRY, A.P. (1966) Lead poisoning in a litter of 5 month old puppies. Vet. Rec. 79, 248.

BLANCHARD, R.L. (1966a) Correlation of Pb-210 with Sr-90 in human bones. Nature (Lond.), 211, 995.

Blanchard, R.L. (1966b) Ratios of Po-210 to Pb-210 in human tissues. Hlth Phys. 12, 1200.

Chakraborty, M., Mukherji, R.N., Bose, A.K., Gopal, A. \& KRISHNAN, N. (1964) An industrial hygiene survey in a lead smelting factory. Indian $J$. ind. Med. 10, 145.

Chow, T.J. \& Johnstone, M.S. (1965) Lead isotopes in gasoline and aerosols of the Los Angeles basin, California. Science, 147, 502.

Cleef, S.A.M. \& VAN Lensing, H.H. (1966) Lead poisoning in chickens. Tijdschr. Diergeneesk. 91, 314.

ClegG, F.G. \& RYlands, J.M. (1966) Osteoporosis and hydronephrosis of young lambs following the ingestion of lead. J. comp. Path. Ther. 76, 15. 
Coghi, L. \& Bellelli, E. (1965) Research on air pollution from a factory for the production of tetraethyl lead. Nuovi ann. Ig. Microbiol. 16, 356.

Crawford, M.D. \& Morris, J.N. (1967) Lead in drinking water. Lancet, ii, 1087.

EtTINGer, M.B. (1967) Lead in drinking water. Water and Water Eng. 4, 82.

Everett, J.L., DAy, D.L. \& Reynolds, D. (1967) Comparative survey of lead at selected sites in the British Isles in relation to air pollution. Food Cosmet. Toxic. 5, 29.

Ferm, V.H. \& CARPENTER, S.J. (1967) Developmental malformation resulting from the administration of lead salts. Exp. molec. Pathol. 7, 208.

Fothergill, R., Kipling, M.D. \& Weber, A.B. (1967) Lead poisoning in jewellery enamellers. Brit. J. ind. Med. 24, 333.

Fullerton, P.M. (1966) Chronic peripheral neuropathy produced by lead poisoning in guinea pigs. $J$. Neuropath. exp. Neurol. 25, 24.

GhelberG, N.W., Goran, I. \& Cheziv, I. (1966) 5hydroxy indoleacetic acid excretion in a population chronically exposed to low atmospheric lead content. Igiena (Buc.), 15, 87.

Hadjimarkos, D.M. (1966) Trace elements in public water supplies and dental caries. Archs environ. Hlth, 13, 102.

HAmenCe, J.H. (1966) Pesticide residues-the public analyst's point of view. Chemy Ind. 29, 1255.

HARDY, H.L. (1966) What is the status of knowledge of the toxic effect of lead on identifiable groups in the population? Clin. Pharmac. exp. Ther. 7, 713.

Horiuchi, K., Horiguchi, S. \& Suekane, M. (1959) Studies on the industrial lead poisoning. Osaka Cy med. J. 5, 41.

Iosif, C. (1966) Acute and chronic lead poisoning in cattle. Red. Med. vet. Ec. Alfort, $142,95$.

JAMES, L.F., LAZAR, V.A. \& BinNs, W. (1966) Effects of sublethal doses of certain minerals on pregnant ewes and foetal development. Amer. J. vet. Res. 27, 132.

Johnson, R.E., Rossano, A.T. Jr. \& Sylvester, R. (1966) Dustfall as a source of water quality impairment. J. Sanit. Engng Div. Amer. Soc. civ. Engrs, 92, 245.

Kauranen, P. \& Miettinen, J.K. (1966) 210-Po and 210-Pb in Environmental Samples in Finland. U.S. Atomic Energy Commission Document N.P. 16002.

KeHOE, R.A. (1966) Criteria for human safety for the contamination of the ambient atmosphere with lead. 15th Int. Cong. Occ. Health, Vienna, Vol. III, p. 83.

Kenoe, R.A. (1967) Statement to Division of Air Pollution Control of Department of Health of Comm. of Pennsylvania. 1st February 1967.

Kehoe, R.A., Cholak, J. \& Story, R.V. (1940) A spectrochemical study of the normal ranges of concentration of certain trace metals in biological materials. J. Nutr. 19, 579.

Kehoe, R.A., Thamann, F. \& Cholak, J. (1933) On the normal absorption and excretion of lead. I-III. $J$. ind. Hyg. 15, 257.

KwoN, S.W. \& KIM, M.S. (1966) Measurements of the degree of atmospheric pollution in Seoul, Korea. Chem. Abstr. 65,4521 .

LAmbert, G. \& Nezami, M. (1961) Significance of fallout in the lead-210 balance. Annls Geophys. 21, 245.

LEAD INDUSTRIES ASSOCIATION (1968) Facts about Lead in the Atmosphere, p. 11.
Legge, T.M. \& GoAdby, K.W. (1912) Lead Poisoning and Lead Absorption, p. 35. Edward Arnold, London.

LuCAS, H.F., Jr \& Di Ferrante, E.R. (1966) The Ra226 $\mathrm{Po}^{210}$ and $\mathrm{Th}^{228}$ in bovine bone and teeth. Radiat. Res. 27, 718.

Lutmer, R.F., Busch, K.A. \& Miller, R.G. (1967) Lead from auto exhaust: Effect on mouse bone lead concentration. Atmospheric Environment, 1, 585.

LyUBChenko, P.N. (1966) The blood picture in adolescents after coming in contact with lead. Gig. Sanit. 31, 93.

Ministry of Agriculture, Fisheries AND FoOD (1959) Lead Poisoning in Calves. Animal Health leaflet No. 43.

Mitchell, R.L. \& Reith, J.W.S. (1966) The lead content of pasture herbage. J. Sci. Fd Agric. 17, 437.

Murozumi, M., Chow, T.J. \& Patterson, C. (1966) Concentrations of common lead in Greenland snows. $\mathrm{Nucl}$. Sci. Abstr. 20, 18944.

Murthy, G.K., Rhea, U. \& Peeger, J.J. (1967) Rubidium and lead content of market milk. J. Dairy Sci. 50, 651.

Oyanguren, H. \& Perez, E. (1966) Poisoning of industria origin in a community. Archs envir. Hlth, 13, 185.

PAtterson, C.C. (1965) Contaminated and natural lead environment of man. Archs envir. Hlth, 11, 344.

Pereira, J.F. \& Echandi, E. (1964) Residual arsenic in leaves and seeds of coffee plants sprayed with lead arsenate. Turrialba, 14, 85 .

Petrova, A., Dalakmanski, Y. \& Bakalov, D. (1966) Study of the contamination of the atmosphere by injurious road transport and industrial products. $J$. Hyg. epidem. Microbiol. Immun. 10, 383.

Pierson, D.H., Cambray, R.S. \& Spicer, G.S. (1966) Lead-210, Polonium-210 in the atmosphere. Tellus, 18, 427.

Pocklington, W.D. \& TATton, J.O'G. (1966) Pesticideo residues in foodstuffs in Great Britain. J. Sci. Fd Agric O $17,570$.

Shupe, J.L., Binns, W., JAmes, L.F. \& KeELer, R.F. (1967) Lupine, a cause of crooked calf disease. J. Amer. vet. med. Ass. 151, 198.

Solomin, G.A., Goncharova, T.O. \& Fesenko, W.G. (1965) Self-purification of natural water to lead ions. Gidrokhim. Matev. 39, 145.

Stewart, W.L. \& Allcroft, R. (1956) Lameness and poor thriving in lambs in farms on old lead mining areas in the Pennines. Vet. Rec. 68, 723.

TAussig, F.J. (1936) Abortion, Spontaneous and Induced, pp. 111 and 354. Kimpton, London.

Thomas, H.V., Milmore, B.K., Heidbreder, G.A. \& KogAN, B.A. (1967) Blood lead of persons living near freeways. Archs envir. Hlth, 15, 695.

Truffert, L., LebBe, J. \& Chovin, P. (1966) Atmospheric pollution in the area of Paris by autmobile exhaust gases. Z. Präv. Med. 11, 134.

Turner, W., BAmford, F.N. \& Dodge, J.S. (1967) Lead poisoning at Bradford. Brit. med. J. iii, 56.

VAN DER KERK, G.J.M. (1966) New developments in organolead chemistry. Ind. Engng Chem. ind. (int.) Edn. 58, 29.

WarRen, H.V. \& Delavault, R.E. (1962) Lead in some food crops and trees. J. Sci. Fd Agric. 13, 96.

WILSON, A.T. (1966) Effects of abnormal lead content of water supplies on maternity patients. Scott. med. J. 11, 73 .

ZIEGFELD, R.L. (1964) Importance and uses of lead. Archs envir. Hlth, 8, 202. 